\section{Besættelsens illegale tryk Fra den første famlen til den problematiske sejr}

af forfatteren John Fellow Larsen

\section{Censuren den 9. april - og for}

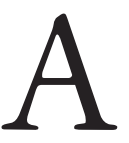
llerede i de første tyske krav, som blev overgivet til udenrigsministeriet den 9. april, hed det, at presse og radio skulle have "Ordre til kun at bringe militære Efterretninger med Samtykke fra de tyske Værne-

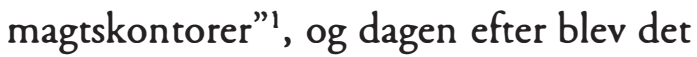
skåret ud i pap i et memorandum:

"Samtlige Organer for den danske Presse, de Telegrambureauer, der arbejder sammen med Pressen, og Ledelsen af alle de Radioudsendelser, der fortsat vil finde Sted, maa officielt underrettes om, at hele Efterretningstjenesten og Kommenteringen af alle Efterretninger maa ske paa en Maade, der ikke kan skade de tyske militære Formationers Interesser. Presse og Radio maa tværtimod se deres Hovedopgave i at virke beroligende paa Befolkningen.

Desuden maa der træffes egnede Forholdsregler for effektivt at forhindre en anti-tysk Propaganda paa ethvert tænkeligt propagandistisk Omraade (Flyveblade, Brochurer, Foredrag ved Foredragsholdere etc.)."2

Hvad tyskerne krævede, var indførelsen af censur i Danmark, og dermed var forudsætningerne for, at der kunne opstå en illegal litteratur i et land, hvor ytrings- og trykkefriheden ellers er en grundlovssikret ret, til stede.
Vi må tænke os en verden ikke blot uden tv, men også med langt færre radioer og med langt færre sendetimer end i dag. Til gengæld blev der lyttet på en anden måde, radioen kværnede ikke, man lukkede op og hørte efter, og i 1940 var det ikke en selvfølge, at det var mediernes opgave at virke beroligende. Det var en helt anden tid dengang. Men de tyske nazister havde $\mathrm{i}$ deres propaganda fra begyndelsen forstået at udnytte de nye medier, film og radio, og de havde allerede erfaringer nok til at forudse modpropaganda endnu før danskerne havde tænkt på en sådan.

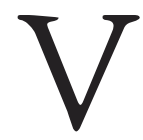

i er vant til at betragte den tyske besættelse som noget, der fandt sted fra den ene dag til den anden: Den 9. april vågnede danskerne op og var besat. I militær forstand var det naturligvis sådan, men gælder det ytringsfriheden, var indskrænkningerne i virkeligheden kommet snigende allerede før besættelsen.

I Wilhelm Bergstrøms dagbog - Wilhelm Bergstrøm var politireporter på Politiken - kan man under datoen 12. september 1939 , altså få dage efter 2. verdenskrigs udbrud, læse følgende:

"Den store Sensation i aften var Skud paa en tysk flyver. I Ritzau kom der en afbrudt sætning om Begivenheden. Saa kom der nogle Prikker. Derefter sætningen: Bedes ikke anvendt. Redaktør Hassager ringede til Pressesekretær Eskelund i Udenrigsministeriet. Denne anmodede om, at Begivenheden ikke blev nævnt i Avisen. Efter hvad jeg erfarede, var der sket følgende. Dragør 
Fortet havde skudt paa en tysk flyver, der havde været inde paa dansk territorium. Antageligt et Skræmmeskud. Flyveren var i hvert fald ikke bleven ramt. Ægte radikalsk. Begivenheden skulde luskes ud af Verden. Udenrigsministeriet havde anmodet om, at det ikke blev nævnt. Vi vil ikke engang være bekendt at vi værger vor Nevtralitet. I Holland og Belgien skyder de rask væk på alle Flyvere, som ikke respekterer Nevtraliteten. Og de er deres Skud bekendt. Herregud man behøvede ikke lave et større Nummer ud af det. Bare bekende kulør. Antagelig faar Fortets Kommandant nu en Reprimande. Jammerligt, jammerligt." 3

Denne scene på en dansk avisredaktion fandt altså sted 7 måneder før den tyske militære besættelse af Danmark, men scenen og vilkårene for den danske presse i besættelsesårene er allerede sat. Det var ikke først 9. april, der blev indført censur, selv om den efter denne dag blev skrappere, og nok var der under besættelsen tale om tysk censur, men langt hen ad vejen blev censuren, indtil bruddet imellem besættelsesmagten og regeringen 29. august 1943 , udmøntet som selvcensur, der blev administreret af det danske udenrigsministerium og den danske presse selv, og efter 29. august fungerede udenrigsministeriets pressebureau endog videre som formidler imellem tysk censur og dansk presse.

Ikke blot er scenen sat; den Eskelund, som Politikens redaktør pligtskyldigt ringer til efter Ritzaus meddelelse om skuddet mod en tysk flyver for at få at vide, at han ikke må bringe ny- heden, er allerede den Karl Eskelund, chef for udenrigsministeriets pressebureau, som under hele besættelsen var den ansvarlige for censurudøvelsen - af nogle bedømt som skurken selv, af andre som en dygtig stødpude mellem tyskerne og de enkelte blade, der forhindrede, at det gik endnu værre.

Nok skærpede 9. april censuren, og den gjorde den almindelige dansker opmærksom på den, men den begyndte ikke 9. april - den var kommet snigende igennem flere år, og når den danske presse kunne leve så forholdsvis smertefrit under censur langt ind $i$ besættelsestiden, hører det med til forklaringen, at censuren netop ikke kom med ét slag. Det var ikke først efter 9. april, at kontakten til udenrigsministeriets pressebureau blev en del af redaktionernes daglige rutine.

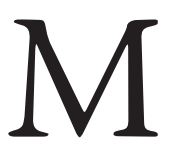

an plejer at sige om Berlingske Tidendes udenrigsredaktør, Nicolai Blædel, at han var den første dansker, som fik skriveforbud af tyskerne allerede 9. april. Det var dog først 12., man nåede til en ordning imellem udenrigsministeriet og tyskerne, for selv om danskerne samarbejdede, kunne tyskerne trods alt ikke nå det hele den første dag, og fuldstændigt skriveforbud fik Nicolai Blædel ikke; han måtte fortsat beskæftige sig med det, som tyskerne kaldte "neutral, litterær virksomhed", blot han fratrådte sin stilling som politisk skribent ved Berlingske Tidende.

Blædels fortsatte skriveri under krigen blev imidlertid ikke neutralt, men resulterede i værket Forbrydelse og Dum- 
hed, som udkom efter befrielsen, og som handler om stormagtsspillet $\mathrm{i}$ trediverne, om nazismens forbrydelser og de andres blinde dumhed, og indtil han døde af sygdom i december 1943, blev Blædel desuden en af hovedmændene bag Danske Tidende, der er blevet kaldt et af besættelsestidens mest velskrevne illegale blade.

\section{Længe før krigen brød ud og}

Danmark blev besat, havde Blædel skrevet både $\mathrm{i}$ sin avis og i pjecer og bøger og talt i radioen om forbrydelserne og dumhederne, og han var derved kommet til at demonstrere, at der var grænser for ytringsfriheden også i det neutrale Danmark før krigen og besættelsen. Efter Münchenforliget i 1938, der ved at ofre Tjekkoslovakiet havde lagt grunden til den fred i vor tid, der kun varede et år, deltog Blædel ikke i den almindelige begejstring, men refererede i stedet, hvad en engelsk politiker, der netop var kommet flyvende hjem fra Prag, havde fortalt i det engelske underhus: Han havde set en ung Tjekkisk kvinde med hagekorset indbrændt med gloende jern på brystet, og en læge havde fortalt ham, at han havde behandlet et 8 måneder gammelt barn, på hvis pande ligeledes et hagekors var indbrændt.

Det tyske gesandtskab protesterede straks, og dagen efter måtte Berlingske Tidende "beklage fremkomsten af disse Linier, idet der i Beretningen om en i sig selv lidet troværdig og i hvert Fald for os ukontrollabel Episode kan indlægges en Antydning af, hvorledes den tjekkiske Befolkning som saadan kan ventes at blive behandlet. Formodninger af denne Art ligger Berlingske
Tidendes ansvarlige Ledelse fjernt." ${ }^{4}$

Dette var imidlertid ikke tilstrækkeligt; Blædels udenrigspolitiske radioudsendelser måtte også ophøre, og avisen sendte ham på ferie. Mens han var borte, opstod der rygter om, at der havde været tale om tysk pression, men derom skrev en anden fri avis i vort endnu fri land, nemlig Politiken:

"Der foreligger intet om et tysk Pres overfor danske Bladredaktioner. Der foreligger derimod dette ved "Berlingske Tidende", at en fejlagtig anlagt udenrigspolitisk Linie, der paa ingen Maade har været til Gavn for de nationale Interesser, eksploderede i en Desperation, som Bladet nødvendigvis maatte tage ubetinget Afstand fra. Tilfældet Redaktør Blædel er beklageligt ... en begavet Skribent med et stærkt lyrisk dramatisk Temperament har ladet sig rive med og ikke tilstrækkeligt forstaaet, at Udenrigspolitik i disse skæbnesvangre Aar hverken er Lyrik eller Dramatik, men nøgtern Virkelighed .."s

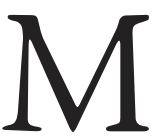
åske var besættelsen et chok, og måske kom den bag på de fleste danskere, men pressen havde øvet sig i besættelsesvilkårene forud. Siden krigsudbruddet havde ytringsfriheden ligefrem været reguleret af et statsministerielt cirkulære, der handlede om de "Hensyn, som Danmarks neutrale Stilling forpligter Pressen at iagttage", og som animerede til selvcensur, idet man " $i$ alle tvivlstilfælde bør henvende sig til Udenrigsministeriets Pressebureau, hvis anvisning bør følges." I modsat fald blev der truet med forbud, hvis overtrædelse da ville medføre straf- 
ansvar. Ikke et ord om grundlovens trykkefrihed; med cirkulærer kan man som bekendt forholde sig friere til loven.

De tyske krav ved besættelsen blev i løbet af kort tid udmøntet $i$ endnu et dansk cirkulære, der blev grundlaget for besættelsestidens censurudøvelse, og dermed for at der kunne opstå en illegal presse, men dette cirkulære var altså blot en videreudvikling af neutralitetscirkulæret fra september 1939, som endda havde sine rødder helt tilbage under 1 . verdenskrig.

De første illegale skrifter

$\mathrm{M}$ an kunne måske have forventet, at den langsomt snigende begrænsning af ytringsfriheden i samme takt havde kaldt nogle illegale skrifter frem, og at disse, som man påstod det efter krigen, straks efter 9. april vældede frem. Men den almindelige dansker havde netop ikke oplevet censuren før besættelsen og kendte formodentlig i 1940 knap nok ordet illegal, og mange journalister var blevet blaserte og havde lært sig at leve med vilkårene. Der var ingen, der fra begyndelsen kunne forudse, at de meget spæde spirer til en illegal presse, som vitterligt hurtigt viste sig, i løbet af de 5 år skulle udvikle sig til mere end 600 illegale blade, der ganske vist ikke alle sammen udkom samtidig, til illegale forlag, der udsendte flere hundrede illegale bøger, og bag det hele et illegalt pressebureau, der også sendte nyhederne ud af landet, og dermed via svensk og engelsk radio i krigens sidste tid gjorde den illegale presse overflødig, i hvert fald hvad nyhedsformidlingen angik.
Et af de mest kendte og omtalte illegale skrifter skal angiveligt være blevet til allerede den 9. april: "10 Bud for Danskerne." Det er den senere leder af organisationen Studenternes Efterretningstjeneste, Arne Sejr, der i 1940 var gymnasiast i Slagelse, der har bragt historien om de ti bud til torvs. Den 9. april oplevede han tyskernes indtog $\mathrm{i}$ Slagelse; han overværede, at et tysk militærorkester allerede samme dag stillede sig op på torvet og spillede "Kong Kristian", og han blev så rasende over danskernes holdning, at han samme aften satte sig og skrev 30 eksemplarer af de 10 bud:

1. Du maa ikke tage Arbejde i Tyskland

2. Du skal lave daarligt Arbejde for tyskerne

3. Du skal arbejde langsomt for tyskerne

4. Du skal ødelægge vigtige maskiner og Værktøj

5. Du skal ødelægge alt, hvad der gavner tyskerne

6. Du skal forsinke alle tyske Transporter

7. Du skal boykotte tyske og italienske Film og Blade

8. Du maa ikke handle hos Nazister

9. Du skal behandle Landsforræddere efter Fortjeneste

10. Du skal værne enhver, som forfølges af tyskerne ${ }^{6}$

ådan lød ordene den 9. april - eller gjorde de? Det er næppe sandsynligt, at en gymnasiast på besættelsens første dag skulle forudse sabotagen og tysklandsarbejderne, ligesom forsinkelsen af de tyske troppetransporter og butiksejeres fraternisering med nazister- 
ne tilhører en senere fase af besættelsestiden. Vi kender da i dag heller ikke et eneste eksemplar af de 10 bud, som Arne Sejr efter eget udsagn skal have skrevet med gennemslag på skrivemaskine 9 . april og smidt i postkassen til prominente borgere i Slagelse 10. april. Hvad vi kender er en kommunistisk udgave af de ti bud fra februar 1943, og fra en politirapport ved vi, at dette illegale tryk den 18.2.1943 var slået op på en skoleport i Slagelse, hvor tyskerne var indkvarteret. I denne version lyder det første bud: Du maa ikke tage Arbejde i Tyskland eller Norge. Arne Sejr har ganske vist udeladt Norge i sin påståede "oprindelige" version af budene, som han har gengivet dem i sin bog om Studenternes Efterretningstjeneste, En Kamp for Fribed, der udkom i 1995, men vi må slå fast, at hvis de 10 bud overhovedet blev til 9 . april, havde de en ganske anden ordlyd.

Der er imidlertid bevaret et eksemplar af et primitivt flyveblad fra Studenternes Efterretningstjeneste, som Arne Sejr ikke nævner, med 10 andre langt mere ordrige bud. Det er dateret november 1940, hvor organisationen endnu ikke var dannet! og da dateringen ikke er med samme skrivemaskine som hovedteksten, kan den være påført senere. På dette flyveblad lyder det tredje bud: "Lad være med at tale ondt om regeringen nu. Forskellen mellem din og dens Mening er, naar det kommer til Stykket kun en Bagatel, og det er ikke Tidspunktet, hvor vi skal splittes, men hvor vi skal samles, samles til en enig national Blok, der kan taale Tryk fra alle Sider. TAL DERFOR DEN NATIONALE ENHEDS SAG."
Dette er helt andre toner end Arne Sejrs efterkrigsskildringer af det raseri med dårlig smag i munden over for regeringens budskaber, der fandt udløsning $i$ at han skrev de 10 bud om aftenen 9. april. Der er også andre urimeligheder i Arne Sejrs version af historien om Studenternes Efterretningstjeneste, og man bør være på vagt over for efterrationaliseringer og -mytologiseringer, når man beskæftiger sig med dette stof. ${ }^{8}$



e flyveblade, som vi kender fra besættelsens første måneder, har typisk en anden karakter end de 10 bud. F. eks. cirkulerede forskellige militære indberetninger og øjenvidneskildringer fra kampene i Sønderjylland i duplicater og afskrifter, nogle endog med navngiven militærperson som forfatter. Der var i begyndelsen netop, i modsætning til de 10 bud, tale om oplysningsvirksomhed, mere end om modstandspropaganda.

Til de mere interessante hører måske i dag, hvor vi ikke savner oplysninger om hændelsesforløbet 9. april, den tyske værnemagts instruks til soldaterne før invasionen. Nogle trykvarianter angiver, at flyvebladet er blevet til, efter at en tysk soldat har tabt sin instruktion under et lægebesøg i København, nogle gengiver instruksen på tysk, andre på dansk. Her er den på dansk: "Værnemagten bør være sig bevidst, at den ikke betræder Fjendeland, men at Tropperne rykker ind $\mathrm{i}$ Danmark til Beskyttelse af Landet og til Sikring af dets Indbyggere. Derfor vil følgende være af interesse: 
1. Danskerne har en stærk Nationalbevidsthed. Derudover føler det danske Folk sig beslægtet med de skandinaviske Folk.

Altsaa: undgaa alt, som kan krænke den nationale Ære.

2. Danskeren er frihedselskende og selvbevidst. Han afviser enhver Tvang og Underordning. Han har ikke Sans for Militær Disciplin og Autoritet.

Altsaa: Kommander mindst muligt, raab ikke op. Det fylder ham med Modvilje og er virkningsløst. Forklar sagligt og overbevist.

3. Danskeren er i besiddelse af megen Bondesnuhed, Forslagenhed, der grænser til uoprigtighed.

4. Danskeren er materielt indstillet. Hans interesser bevæger sig hovedsagelig om materielle Spørgsmaal. Enhver Indskrænkning i hans Behov, føles sæ̋rdeles haardt.

Altsaa: Indgreb i privat Ejendom maa saa vidt muligt undgaas, al "Rekvireren" og lignende er forbudt. ("Besorgen", "Organisieren" und dasgleichen sind Verboten.)

5. Danskerne elsker en behagelig hjemlig Tilværelse. Han kan vindes ved Venlighed, ved smaa Opmærksomheder og Anerkendelse af hans Person.

6. Det handelsdrivende Folk viser Sympati for England og afskyr Krigen. For det national-socialistiske Tyskland findes med faa Undtagelser ingen Forstaaelse.

Altsaa: undgaa politiske Diskussioner.

7. Det tyske Sprog forstaas af mange Danske."
De store bladgrupper opstår


e tidlige flyveblade, som vi indtil nu har beskæftiget os med, syner naturligvis ikke meget i den store skov af illegale publikationer, hvoraf langt de fleste blev udsendt i krigens sidste halvandet år, men de giver et indtryk af, hvordan det hele begyndte. Historien skrives som bekendt bagfra, men den opleves forfra, og vil man for alvor forstå en historisk periode og ikke blot bekræfte sin egen tid i den, må man i det mindste forsøge at genopleve den forfra, at udelukke al senere bagklogskab, og et uhildet blik på fortiden forudsætter vist, at man først er i stand til at betragte sin egen tid historisk og med en vis distance.

Vi skal frem til efteråret 1941, før der for alvor begynder at ske noget $\mathrm{i}$ illegal sammenhæng; til gengæld sker der flere ting næsten samtidigt. Før dette tidspunkt var det småt med egentlige illegale bladgrupper. Flyvebladene blev udsendt ved særlige lejligheder og som regel af personer og personkredse, som vi i dag ikke kan identificere. Fra årsskiftet 1941-42 begynder flere bladgrupper imidlertid at udsende periodisk udkommende blade.

Startskuddet blev givet med Tysklands angreb på Sovjetunionen den 22. juni 1941, interneringen af de danske kommunister og den grundlovsstridige ulovliggørelse af partiet. Det var ikke blot Hitler, der "endelig kunne tale åbent", som han sagde i det opråb, hvori han orienterede tyskerne om, at korstoget mod øst var indledt; også de danske kommunister var nu med et slag gjort illegale og befriet for den mund- 
kurv, som Hitler-Stalin-pagten havde forsynet dem med.

Da den ulovlige lov, der skulle lovliggøre regeringens, politiets og domstolenes grundlovsstridige handlinger blev forelagt i folketinget 20. august, havde kommunisternes formand, Aksel Larsen, der endnu var på fri fod, tænkt sig at indtage sin plads i folketinget og sige sin mening, men det måtte han opgive, da Christiansborg i dagens anledning nærmest blev besat af politi. I stedet besluttede partiet at udsende "talen, som burde have været holdt", illegalt. Det blev til besæettelsens første større illegale publikation, den berømte pjece Danske Toner, "Alle danske Hjems Sanghefte!", som der stod på forsiden, " 16 danske Sange med Musik", "Syng dem ved Arbejdet, Syng dem i Hjemmet", "Forlaget "Danske Toner", København 1941". Indholdet var imidlertid ikke 16 danske sange, men en 16 sider lang, vred tale af Aksel Larsen, der redegjorde for grundlovsbruddet og kommunisternes stilling.

Børge Houmann stod for det praktiske arbejde med publikationen. ${ }^{10}$ Han havde allerede før krigen beskæftiget sig med illegale publikationer, nemlig med de tyske såkaldte Tarnschriften (kamuflerede tryk), antinazistisk propaganda, hvoraf ikke så lidt blev fremstillet netop i Danmark. Pointen er, at man slører en illegal publikations indhold, for så meget lettere at kunne sprede den. I "Danske Toner"s tilfælde er kamuflagen nok så meget en ironisk kommentar til danskernes foretrukne manifestationsform, alsangen; for kommunisterne var modstanden blodig alvor. Houmann har fortalt, at partiledelsen og Aksel Larsen blev fortørnet over den pjattede titel på en højaktuel alvorlig politisk tale, men da var omslaget i trykken.

Det var ikke nogen let sag at producere og distribuere en illegal tryksag som Danske Toner i 15.000 eksemplarer i 1941, selv ikke for kommunisterne, der i tide havde forberedt både en illegal organisering af partiet og illegale trykkegrupper. Da talen dupliceret ville blive for besværlig at distribuere pr. post, måtte den trykkes, men de trykkerier, som kommunisterne var vant til at benytte, turde ikke udføre det ulovlige arbejde, navnlig turde man ikke sætte skriftet af frygt for, at man via satsen skulle kunne spore trykkeriet.

Løsningen blev, at man nedfotograferede det maskinskrevne manuskript og fik fremstillet klicheer, en metode som også andre illegale blade senere brugte for at formindske tryksagerne og gøre dem lettere at transportere og distribuere. Børge Houmann fandt en mand, som var ansat på en klichéanstalt på Vesterbrogade, men ejeren var stokreaktionær og faktoren var nazist og optrådte i skaftestøvler og sortskjorte. Klichéerne måtte altså fremstilles om natten - med "lånt" nøgle. Selve arbejdet tog to nætter. Dernæst vovede et trykkeri i Rådhusstræde at trykke "for gammelt bekendtskabs skyld".

Omslaget blev fremstillet $i$ en lille forretning i Griffenfeldtsgade, som ellers levede af at trykke konfirmationsog festsange; her tjente kamuflagen altså også et formål. For at kunne skære trykkestedet bort, bestilte man formatet nogle centimeter for stort. Alligevel blev 
trykkeren opsporet af politiet, som dog måtte erkende, at han kunne have været i god tro - hvad han faktisk var.

Før skriftet kunne udsendes, skulle der også skrives mellem 12 og 14.000 kuverter. Det foregik hos Trille og Kjartan Munck på Kastelsvej - efter alt, hvad der lod sig fremskaffe af adresselister: Lægeforeningens medlemmer, sagførere over hele landet efter rigstelefonkataloget, alle arbejdsmandsforbundets afdelinger, alle fagforbund, brugsforeningsuddelere, dyrlæger, lærere osv. Men bladet skulle også samles og omslaget skæres til. Dertil fik man fat i en kvindelig bogbinder og flere af hendes kammerater og installerede dem $\mathrm{i}$ en lejet kælder på Nørrebro.

Endelig kunne Houmann transportere hele materialet til lejligheden på Kastelsvej, hvor man nu kun manglede at lægge de små 15.000 tryksager i kuvert og frankere. Den 24. september 1941 lå Danske Toner klar til udgivelse. Trille og Houmann kørte i taxa til banegården med fire tunge kufferter og indskrev dem som rejsegods til henholdsvis Odense, Fredericia, Århus og Ålborg. Dernæst tog Trille toget til de fire byer, hvor hun på kontaktadresser afleverede de fire rejsegodsbeviser og en besked om, at man ønskede de mange breve postet rundt omkring i de fire byer og nabobyer 26 . september om eftermiddagen. Den 27. - godt en måned efter at talen burde have været holdt i folketinget - udkom altså Danske Toner, bragt ud til næsten 15.000 danskere af postvæsenet - restoplaget blev fordelt på arbejdspladserne gennem de illegale partiafdelinger. Københavnerne modtog brevet fra provinsen, og i provinsen modtog man brevet fra København eller fra en af de andre provinsbyer. Det var ikke let at spore, hvordan de illegale toner var blevet til.

Med Danske Toner havde kommunister med al ønskelig tydelighed demonstreret, at aktionen imod dem hverken havde udslettet dem eller lammet dem. Og at der fulgte mere efter, det tør siges. Fra oktober samme år udsendte man Politiske Maanedsbreve, som fra marts 1942 skiftede navn til Land og Folk, og som oplagsmæssigt blev besættelsestidens største illegale blad. I 1944/ 45 var oplaget for et enkelt nummer sandsynligvis helt oppe på 120-130.000 eksemplarer.

Hvordan var dette kæmpemæssige arbejde organiseret?" - Øverst havde man en illegal landsledelse, som bestod af Alfred Jensen, Børge Houmann og Thorkild Holst og naturligvis Aksel Larsen, indtil han blev sat ud af spillet ved arrestationen i november 1942. Formelt var denne landsledelse et forretningsudvalg under centralkomiteen, men da det var vanskeligt og forbundet med stor risiko at indkalde centralkomiteen i den illegale tid, fungerede de fire mand i landsledelsen, som under hele krigen opholdt sig i København, i praksis som centralkomite, og de underskrev sig da også som sådan.

Redaktionsarbejdet og organiseringen af arbejdet med de illegale publikationer var det først og fremmest Børge Houmann, der tog sig af. Først blev manuskripterne skrevet på maskine med gennemslag i op til 20 eksemplarer, der blev fordelt til distriktsledelserne i 
hovedstadsområdet og ved hjælp af rejsesekretærer til de lokale ledelser i provinsen. I København kunne en distriktsleder have flere underdistrikter og trykkegrupper under sig, og han måtte derfor selv i gang med at skrive af og give videre, før de enkelte grupper kunne gå i gang med at skrive stencils og duplicere.

Udover de mange lokale grupper, der fremstillede bladet efter manuskript fra hovedledelsen, stod hovedledelsen selv for fremstillingen af en central udgave, som blev sat på egne illegale sætterier og trykt ligeledes på egne illegale trykkerier, men også i perioder på legale trykkerier. Vi kender eksempler på, at det centrale tryk er fremstillet på legale trykkerier både i København, Glumsø og Hundested. Det centrale tryk blev sædvanligvis fremstillet i meget store oplag, som blev fordelt til grupper over hele landet. Et blads findested siger, også af denne grund, ikke nødvendigvis noget om, hvor det er fremstillet.

Teksten i Land og Folk var altså centralstyret. I en intern meddelelse til grupperne fra januar 1942 hedder det: "Ved Mangfoldiggørelsen er det tilladt at udelade noget af Indholdet, hvis det passer bedre med Papirformatet, eller hvis det er for besværligt at faa det hele med." Man havde altså forståelse for praktiske vanskeligheder, men derefter hedder det, at "der maa ikke sættes noget nyt ind, som ikke har staaet i de originale Maanedsbreve." I stedet foreslår man, at man supplerer med lokale bulletiner, og derved opstår der en hel stribe af lokale kummnunistiske blade ved siden af hovedbladet.

Men selv om teksten er ens $\mathrm{i}$ de mange forskellige udgaver af et Land og Folk-nummer, er de lette at skelne fra hinanden. Duplicerede skrifter er jo aldrig ens, men de enkelte trykkegrupper har desuden direkte betræbt sig på at sætte deres eget præg på deres udgave: Typografien i de tegnede bladhoveder er vidt forskellig fra gruppe til gruppe, og karakteristisk nok holder den enkelte gruppe fast ved sit bladhovede gennem hele krigen, og derfor kan vi i dag, når vi sammenholder eksemplarerne i de største offentlige og private samlinger, sige noget om, både hvor udbredt det enkelte nummer var, og med rimelig sikkerhed kan vi fastslå i hvilke perioder de enkelte grupper fungerede. Det første nummer af Politiske Maanedsbreve fra oktober 1941 kender vi i 6 varianter, det sidste illegale nummer af Land og Folk i 28 varianter.

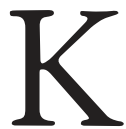

ommunisterne var ikke ene om at tegne billedet i efteråret 1941, men de havde dog et hovedansvar også for den næste organisationsdannelse, jeg vil nævne: Frit Danmark. Her må vi igen leve os ind $\mathrm{i}$ historien forfra. Kommunisterne blev jo tvunget ud i illegalitet, i den forstand var springet altså let for dem, men for den ikke-kommunistiske modstand er det karakteristisk for mange kommer det sikkert som en overraskelse - at den så langt, det overhovedet lod sig gøre, forsøgte at finde legale former.

Besættelsestidens første strejkebølge, Antikominternstrejkerne i slutningen af november 1941, viser det tydeligt. Studenterne mødte op på Amalienborg Slotsplads med en resolution, 
som vi kender fra adskillige efterfølgende flyveblade:

"Som Repræsentant for den Ungdom, der skal bære Fremtidens Danmark, udtrykker vi vor Sorg over, at den danske Regering har sluttet sig til Antikominternpagten. Deres Majestæt skal vide, at vi hellere vilde dele Kaar med det norske Folk, end uden Modstand taale Danmark brugt til et Formaal, der staar i dybeste Modstrid med vor Vilje til at leve i et frit, folkestyret Danmark. Det er vort Haab, at den Tillid, som store Kredse af det danske Folk nærer til Deres Majestæt, maa blive retfærdiggjort ved et ubetinget Afslag af alle Forsøg paa at tilsidesætte det Løfte, som er givet os om Anerkendelse af vor Ret til selv at styre vore indre Forhold. Gud bevare Kongen. Gud bevare Danmark." 12

Naivt tror man, at man kan få Kongen i tale, og at en appel til den Konge, der fra begyndelsen med opfordringer til ro og orden og en værdig optræden har stået bag indrømmelsespolitikken, kan hidføre de norske tilstande, dvs. det brud med besættelsesmagten, som man længes efter! Men statsmagten og politiet tolererede ikke engang, at resolutionen blev læst op. Studenten, der forsøgte på det, blev afbrudt og anholdt, før han nåede til vejs ende i den korte tekst, og i de kommende dage opløste politiet alle demonstrationer og anholdt godt halvandet hundrede mennesker.

Antikomintern-demonstrationerne var temmelig harmløse i forhold til, hvad vi siden har oplevet i fredstid, men for mange deltagere dengang blev de netop den erfaring, der viste, at der ikke var nogen vej uden om illegal modstand. Bladgruppen "De danske Studenter" blev til som en udløber af demonstrationerne, og som den tværpolitiske gruppe, den var, blev den en forløber for det samarbejde imellem kommunister og borgerlige, der kort tid efter resulterede i "Frit Danmark"-organisationen.

Som strejkerne var legale i deres anlæg, var også "Frit Danmark" oprindelig tænkt som et legalt modstandsinitiativ, men udviklingen løb fra ideen, før den nåede at blive realiseret.

Bladet Kultur og Politik, som var blevet udgivet af det venstreorienterede Studentersamfund, var blevet tvunget til at ophøre på grund af kommunistloven. I stedet for det forbudte blad ønskede man at starte et nyt, men det ny skulle have en bredere basis og henvende sig til en større læserkreds. Man inddrog derfor den konservative politiker Christmas Møller, som jo havde mistet alle sine politiske poster, fordi han havde været mere åbenmundet over for besættelsesmagten og nazisterne end andre politikere, og som netop nu var særlig interesseret i modstandskontakter i Danmark forud for sin planlagte afrejse til England.

Forberedelserne til det ny blad resulterede $i$ et stiftende møde 17 . december 1941, hvor bl. a. redaktør på Nationaltidende Ole Kiilerich, som Christmas Møller havde udpeget til sin efterfølger som repræsentant for den borgerlige fløj i projektet, når han selv forlod landet, og Mogens Fog deltog. Tidsskriftet skulle især bringe de oplysninger om de faktiske forhold, som den etablerede presse og de politiske partier 
var forhindret $i$ at bringe, og bladet skulle hedde Fremtiden. Økonomien til det blev bragt i orden, og man begyndte på tilrettelæggelsen af det første nummer - men så havde situationen igen forandret sig.

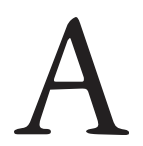

llerede før mødet 17. december havde det første ikke-kommunistiske illegale blad, De frie Danske, udsendt sit første nummer i 200 eksemplarer og dermed vist, at også borgerlige måtte betræde den illegale modstands vej. De frie Danske blev til et af de største illegale blade. Indtil befrielsen udsendte man 34 månedlige numre, der både voksede i sidetal, oplag og i mængden af varianter af de enkelte numre, det sidste et vidnesbyrd om, at det både blev fremstillet af mange forskellige grupper, og at et enkelt sæt stencils langt fra rakte til et oplag - og at man desuden redigerede og satte de sidste nyheder ind i forbindelse med, at man skrev nye stencils. Med gruppens egne ord i en rapport fra lige efter befrielsen: "Foruden de besværlige indkøb af Maskiner, Stencils, Sværte o. l. er der til ca. 672.000 udsendte Ekspl. og ca. 150.000 Løbesedler, ved Opfindsomhed og ukuelig Energi Købt og transporteret 300.000 store Kuverter med Frimærker samt henimod 4 Millioner Ark Papir, der trykte på begge Sider giver 8 Millioner Duplikatortryk. Bladet har i alt kostet 300.000 Kroner at skrive, trykke og udsende." 13

Man forstår umiddelbart, at jeg begår en stor uretfærdighed, når jeg lader De frie Danske optræde som et apropos til skildringen af "Frit Danmark"s tilblivelse. Mit forsvar er, at jeg begår endnu større uretfærdigheder over for de utallige bladgrupper, som jeg slet ikke nævner, og at jeg har valgt at lade den illegale litteraturs tilblivelsesproces være mit hovedemne. Uden en forståelse af processen er en opregning af dens frugter ikke særlig interessant.

$$
\text { Årsskiftet 1941-42 er et knu- }
$$
depunkt i denne proces. Det er slet ikke det store flertal i befolkningen, der er med på vognen endnu; det er tværtimod et lille antal mennesker, det handler om, men det er på dette tidspunkt, at de potentielt aktive ikke længere kan forholde sig passive, og at den grundlæggende struktur i den illegale bladverden bliver til. De frie Danske udsender ikke blot deres første nummer; der er også straks flere grupper, der på eget initiativ begynder at mangfoldiggøre bladet. Det viser, at udviklingen nu ikke mere kunne holdes tilbage, og at den vrangforestilling, som både tyskerne og den danske regering helst havde set bekræftet, nemlig at alle aktiviteterne havde deres udspring hos kommunisterne, var forkert:

En af de modstands-utålmodige, Lars Lassen-Landorph, beretter selv: "Efter at være hjemsendt fra Den Kgl. Livgarde i august 1941 deltog jeg i nogle måneder $i$ et adgangskursus til officersskolen, hvor jeg traf en række ligesindede, bl. a. KU'ere og reserveofficerer. Da studenterdemonstrationerne begyndte i efteråret 1941 forsøgte vi at organisere disse, dog uden resultat. Hele baggrunden for disse demonstrationer var yderst improviseret og dilettantisk. Imidlertid førte disse aktioner til diskussion i en gruppe af spejderførere på Frederiksberg, hvor et par af disse fandt 
sammen om forsøget på "at gøre noget". Bl. a. var Knud Aage Nielsen en af de ivrigste. Han havde været med i Finlandskrigen ...

Gennem lukkede møder hos Lorry på Frederiksberg, hvor dele af den konservative vælgerforening på Frederiksberg blev orienteret om udviklingen af Poul Møller, MF, traf jeg personer, der kendte noget til bladet De frie Danske, og Knud Nielsen og jeg begyndte for os selv at kopiere disse numre. Vi duplikerede et par numre vi fik fat i. Jeg husker, at vi havde det største mas med at efterligne bladets hoved.

Igennem en god ven, fabrikant Tjørn fra firmaet Oscar Meyer fik jeg understøttelse til at indkøbe papir, og snart havde jeg flere garderobeskabe fyldt med indkøbte stabler af denne mangelvare. Dette var begyndelsen til selve vor afdeling til udgivelsen af dette blad, og da Knud Nielsen fik direkte forbindelse til udgiverne og kunne få både det rigtige hoved samt stencils, måtte denne afdeling udvides med spejderkammerater. ..."14

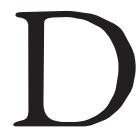

er skete mere endnu i disse måneder. Den 12. december 1941 var lederen af partiet Dansk

Samling, Arne Sørensen, og historikeren Wilhelm la Cour blevet løsladt efter udstået fængselsstraf på henholdsvis 60 og 80 dage. La Cour havde ud fra sit nationalt historiske ståsted i den ene pjece efter den anden propaganderet imod den mangel på fasthed, hvormed samarbejdspolitiken blev ført, mens Arne Sørensen havde været ansvarlig for udgivelsen af pjecerne på partiets forlag: Det tredje Standpunkts Forlag. Flere af pjecerne var blevet beslaglagt, men hver gang havde aktivister i Dansk Samling været i stand til at distribuere hovedparten af oplaget, før man lod politiet få den sidste lille del. Umiddelbart fik beslaglæggelserne først og fremmest propagandaeffekt, men de gav også mange af de aktive i Dansk Samling en træning og skoling, som førte direkte over i det senere egentlige illegale bladarbejde.

Dansk Samlings illegale publikationsvirksomhed hører til besættelsestidens største og betydeligste, men da partiet forsøgte på samme tid at forblive legalt og at handle illegalt, hører den store mængde af illegale publikationer først til efter 29. august 1943. Hovedbladet blev da Niels Jydes Breve, som fra oktober 43 udkom i et væld af udgaver, ligesom Land og Folk og Frit Danmark publiceret af grupper over hele landet. Fra oktober 44 blev Niels Jydes Breve afløst af besættelsestidens største dagblad, Morgenbladet, og Dansk Samling stod desuden bag et af de største illegale bogforlag, Skipper Clements Forlag. Partiets balancegang betød, at dets modstandskamp ikke var nær så centralt styret og fast organiseret som $\mathrm{f}$. eks. kommunisternes, men Dansk Samling-folk var drivkraften i utallige lokale bladgrupper også før 29. august, og de har formodentlig stået bag en betydelig del af de tidlige anonyme flyve-blade.

Wilhelm la Cour var oprindelig konservativ, men gik et skridt videre end Christmas Møller, idet han meldte sig ud af partiet - og ind i Dansk Samling - allerede i anledning af Scavenius' berygtede tiltrædelseserklæring den 8 . 
juli 1940 om "de store Tyske Sejre, der har slaaet Verden med Forbavselse og Beundring", og han var ikke blot skribent, men måske i lige så høj grad provokatør. Tyskerne, der jo fra førkrigstiden havde større erfaring end danskerne $i$, hvordan en modstandsbevægelse opstår, havde fra begyndelsen et godt øje til Wilhelm la Cour, og udenrigsministeriets pressebureau blev hurtigt tvunget til også at beskæftige sig med ham. I modsætning til den legale presse lod la Cour sig imidlertid ikke tale til fornuft. Han erklærede tværtimod over for Eskelund i pressebureauet, at et indgreb over for ham ville være gavnligt, "idet befolkningen så derved måske ville få at se, hvordan den virkelige situation er her $\mathrm{i}$ landet", og da han igen blev indkaldt til samtale, erklærede han, at "hvis der endelig blev taget alvorlige forholdsregler overfor ham, kunne han kun sige, at der herimod ville blive skredet ind fra meget høj side"15. Det var Kongen Wilhelm la Cour tænkte på; den lidt verdensfjerne tro på at Kongen kunne og ville gribe ind, var studenterne altså ikke ene om.

Også løsladelsen fra fængslet i december 41 var planlagt med demonstration for øje. Wilhelm la Cour og Arne Sørensen havde ligefrem formået myndighederne til at fastsætte begyndelsen på deres afsoning, sådan at de blev løsladt samtidigt, men mens de var fængslet, havde studenterurolighederne fundet sted, og nu forhindrede man, at løsladelsen udviklede sig til demonstrationer ved at køre de to til hovedbanegården og sætte dem fri dér og ikke fra Vestre Fængsel som forventet. Selv om la Cour var ældre end de fleste af de akti- vister, der var begyndt at dukke op - han var i 194158 år gammel - og selv om hans udgangspunkt var dybt konservativt og nationalromantisk, så bedrev han altså som en senere tids venstreorienterede provokatorisk anskuelsesundervisning.

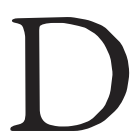
et var "Frit Danmark", vi kom fra. Mens man var i færd med at forberede det ny legale tidsskrift Fremtiden, blev der nemlig atter røre om Wilhelm la Cour, som på fri fod straks havde genoptaget sin foredragsvirksomhed. Efter et foredrag på Damhuskroen 4. februar 42 blev han igen anholdt, og mange af tilhørerne blev afhørt, denne gang af de tyske myndigheder, og selv om sagen endte $i$ en dansk retssal, viste det, at vilkårene for at ytre sig var blevet snævrere og den tyske indblanding større. Episoden gav anledning til en hel række flyveblade ${ }^{16}$, og det var ikke mere let at tro, at det havde nogen mening at forsøge at sprede oplysning i et legalt tidsskrift.

Den 4. februar var desuden Georg Brandes' 100 års dag, og det havde Studentersamfundet sat sig for at fejre ved et arrangement på Borups Højskole den 3. "Kommunistsammenslutningen "Studentersamfundet" fejrer i Aften Jøden Georg Brandes" stod der samme dag hen over forsiden på de danske nazisters af tyskerne finansierede avis, Fadrelandet. Et foredrag om Brandes i radioen blev aflyst. Justitsministeren indkaldte Studentersamfundets bestyrelse til møde og forsøgte forgæves at overtale den til at aflyse arrangementet - eller i det mindste stryge Elias Bredsdorff af talerlisten. 
Men mindeaftenen blev afholdt - under overværelse af civilklædte betjente. Bagefter kritiserede den tyske gesandt Renthe-Fink, at regeringen havde ladet kommunister tale offentligt. Justitsministeren forsvarede sig med, at der kun var tale om "Salon-kommunister", men forbød ikke desto mindre udgivelsen af en pjece med talerne fra festen.

Hovedtaleren var Hartvig Frisch, som siden sin ungdom var både antinazist og antikommunist. Han talte om Brandes' forhold til Hellas, og han sluttede sin tale med Renans bøn til Athene i Brandes' egen gengivelse: "Verden vil alene kunne frelses ved at vende tilbage til dig og saaledes ryste det Barbari af sig hvori den forkommer. Jeg vil lære dit Sprog ... Jeg vil af mit Hjerte uddrive hver Fiber, som ikke er Fornuft og ren Kunst." ${ }^{17}$ - I 1942 farlige betydningsladede ord, đer måtte forbydes. Hvilken betydning har de ord, der siges i dag? Er det lov, at ord taber i kraft, når de er tilladt? kunne vi spørge.

Tiden var altså forpasset til et legalt blad. 'Fremtiden' måtte blive til 'Frit Danmark'. Det måtte det også, fordi Christmas Møller havde ønsket at inddrage Aksel Larsen, og da denne derefter indbød til et personligt møde, var det med henblik på udgivelsen af et illegalt blad. Som de allierede og russerne fandt sammen på verdensplan efter USAs indtrædelse i krigen i december 41 , fandt kommunisterne og de borgerlige sammen i Danmark, og vi kan trække parallellen videre: Ligesom Sovjetunionen kom til at bære de største byrder på krigsskuepladserne, kom kommunisterne navnlig i begyndelsen til at trække det største læs, hvad det praktiske bladarbejde angik. Man stræbte imod, at det første nummer skulle udkomme på 2 -årsdagen for besættelsen. Mange steder $i$ besættelseslitteraturen er det blevet til, at bladet faktisk udkom den 9. april; det gjorde det ikke; det udkom den 22. april i 5000 dublikerede eksemplarer. ${ }^{18}$

Christmas Møller havde skrevet programartiklen, hvori det bl. a. hed:

"Vi er en lille Kreds, som tidligere har haft meget modsatte Anskuelser, og som maaske vil blive uenige igen, naar Forholdene i Danmark tillader os at tale frit og aabent som i gamle Dage. I Dag er vi traadt sammen for at udgive Frit Danmark, for at holde den danske Linje, for at give vore Landsmænd aaben og ærlig Besked om, hvad der foregaar, for midt i Undertrykkelsen at tale saaledes som det er klart for alle, at der tænkes i de 99 pCt. af Befolkningen." 19

Børge Houmann var igen den praktiske organisator. De kommunistiske grupper betjente dublikatorerne og overkom oven i deres egne publikationer nu også Frit Danmark. Mens folketinget havde forbudt kommunisterne, havde andre borgerlige kredse hårdt brug for dem i det praktiske modstandsarbejde.

Der forestod et stort arbejde med at bygge "Frit Danmark"-organisationen op. Det skete langsomt, men støt, og i det store hele efter den kommunistiske model med rejsesekretærer, faggrupper i København og lokalgrupper $i$ resten af landet. Den afgørende forskel var, at de to organisationer henvendte sig til forskellige befolkningsgrupper, Land og Folk til arbejderne, Frit Danmark til borgerskabet, og at Frit Dan- 
mark var mindre stramt styret. Holdningerne i de to organisationer blev ikke pr. definition ens, og der er eksempler på, at lokalgrupper gik deres egne veje. Det var det manuelle trykkearbejde, der var mest afhængigt af kommunisternes arbejdskraft, men også her lykkedes det mange steder for Frit Danmark, f.eks. i Odense, at skabe sig sit eget produktionsapparat.

Lad os slutte denne skildring af det illegale bladarbejdes tilblivelse hos en menig slider, med et lille uddrag af maskinarbejder Poul Christensens erindringer. Poul Christensen var straks 22. juni 1941 blevet heltids illegal, og i slutningen af november samme år, altså netop i denne grødetid for den illegale litteratur, ankom han som sit partis udsending til Esbjerg, hvor han ustandseligt måtte flytte rundt:

"Derefter boede jeg en uges tid hos papirhandler Tobiesen. De havde en dejlig villa, og jeg sov på en feltseng $\mathrm{i}$ kælderen. Jeg kom først op i stuerne, når børnene var lagt i seng. ... Til sidst lykkedes det mig at få et værelse i Havnegade 136. Ejeren, som var snedker, boede på anden sal og var indforstået med arrangementet. Her boede jeg hele sommeren, men opholdt mig ikke på værelset om dagen. Jeg kørte gerne ud om morgenen ved almindelig kontortid og vendte hjem ud på aftenen. I stuen boede en organiseret nazist, som arbejdede i Oksbøl. En aften, da jeg vendte hjem, var fortovet foran huset fyldt med nazister i fuld uniform. Jeg troede i første øjeblik, at de var kommet for at arrestere mig, men de havde været på besøg hos nazisten og var nu ved at køre bort i to tyske biler.
Jeg fik kosten efter et specielt system. Det var postbud Milter Jensen, som havde fået det organiseret. En uge har 7 dage, og jeg spiste 7 forskellige steder. Når der var gået nogen tid, flyttede jeg andre steder hen. Det var ikke særlig illegalt, men man kom til at kende en masse mennesker, og fik kontakt med mange folk, som gerne ville hjælpe os med en lille opgave. Det var samtidig en fin og god kost. Når der en enkelt dag kom en fremmed mand og spiste, blev der gerne lavet lidt ekstra til ham. For at jeg ikke skulde overrende dem, kom jeg kun og spiste to gange om dagen. Det var lang tid at gå til middag, når man ikke havde fået nogen morgenmad. Jeg fik fra nu af ikke udbetalt flere kostpenge af partiet.

\section{I april 1942 udkom det første} nummer af Frit Danmark. I Esbjerg blev der dannet en lokal afdeling. Jeg fik til opgave at trykke og fordele bladet. Det første nummer fik vi færdig fra Odense, men fra nr. 2 mangfoldiggjorde vi et antal eksemplarer. Vi begyndte med et oplag på 400, og det steg støt for hvert nummer. "Frit Danmark" blev udsendt igennem postvæsenet, og det var et stort arbejde at få lagt alle disse breve i postkasserne. Det var begrænset, hvad der kunne være i hver kasse. Jeg fik $20 \mathrm{kr}$. om dagen, når jeg arbejdede for "Frit Danmark". Det var den eneste indtægt, jeg havde under mit ophold i Esbjerg. Lidt udgifter havde man trods alt. F. eks. brugte jeg en del penge til aviser.

Efterhånden blev der meget at gøre med bladene. Arbejdet med at stencilere, trykke, hæfte og fordele tryksagerne tog næsten al min tid. Når mate- 
rialet var færdigt, cyklede jeg tit en tur til Varde, Vejen og Ribe for at forsyne kammeraterne dér med blade og sludre lidt med dem om tingene. Til Tønder, derimod, gik pakken gerne med toget. Dertil nåede jeg aldrig. Der var stadig fremgang og større og større oplag. Det medførte også, at det indsamlede beløb til det illegale arbejde blev større. Når kammeraterne kom med en tryksag, var det ikke svært at få et lille beløb af vedkommende. Vi havde dog også forbiere. En gårdejer i Skads, som en kammerat en dag havde talt med, og overfor denne givet udtryk for sin tyskfjendtlige holdning, fik tilsendt vores materiale. En dag fik postvæsenet af politiet forevist noget af materialet og blev forespurgt, om de kendte håndskriften. Det var min skrift! Manden kunde have brændt tryksagerne, hvis han var bange for at opbevare dem. Han behøvede ikke at rende til politiet med dem....

I august begyndte partiet at udsende et lokalt blad, der blev kaldt "Vestjyden". I Odense havde man et lokalt blad, der hed "Trods alt". Det var forbillede for bladet, vi satte igang i Esbjerg, og som jeg blev leder af. Særlig stor betydning fik disse blade for de kommende folkestrejker. ${ }^{20}$

\section{De illegale blades sejr}

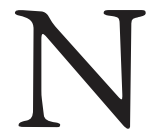

$\mathrm{u}$ er der kommet gang i de illegale blade. Nu begynder den egentlige historie. Den springer vi over! Tilbage står enden på det hele. Vi gør som romanlæseren, der utålmodigt springer til slutkapitlet, når han er kommet ind $\mathrm{i}$ handlingen.

Den 5. maj var det slut med hele herligheden: 24 millioner illegale blade var det blevet til. Det kan ikke have været ret mange danskere, der ikke nåede at have et illegalt skrift $\mathrm{i}$ hånden. Modstandssynspunktet, som var den illegale presses hovedbudskab, havde sejret, og aldrig så snart var de legale aviser igen fri, før de fortsatte, hvor de illegale slap - og som politikerne glemte de alt om, hvad de havde ment og skrevet i de foregående år.

Man kan roligt sige, at det var ikke, hvad de illegale havde ventet og forberedt sig på. Tværtimod var mange af den opfattelse, at de legale aviser havde kompromitteret sig selv $i$ en sådan grad, at de måtte lukke ved befrielsen, og at den illegale presse måtte overtage hele nyhedsformidlingen og dagbladsproduktionen og altså fortsætte i en legal tilværelse. Det var endda ikke en specielt dansk opfattelse. Den senere tyske forbundskansler Willy Brandt var i Stockholm, hvor han under krigen var leder af den norske nyhedsformidling, involveret $i$ et projekt, der gik ud på ved hjælp af kapitalstærke kredse i England at oprette et internationalt finansieringsinstitut, der skulle stille midler til rådighed til den illegale presse, så den kunne fortsxtte som en fri, legal presse efterhånden som befrielsen skred frem i Vesteuropa. ${ }^{21}$ Men der blev ikke brug for initiativet; man havde undervurderet menneskets og i dette tilfælde specielt journalisternes evne til at skifte holdning og tilpasse sig. Alligevel ligner historien om den illegale presse en eklatant succeshistorie. Den egentlige modstand var ganske vist sabotagen. Sådan var det i hvert fald i mange år efter krigen. Man frem- 


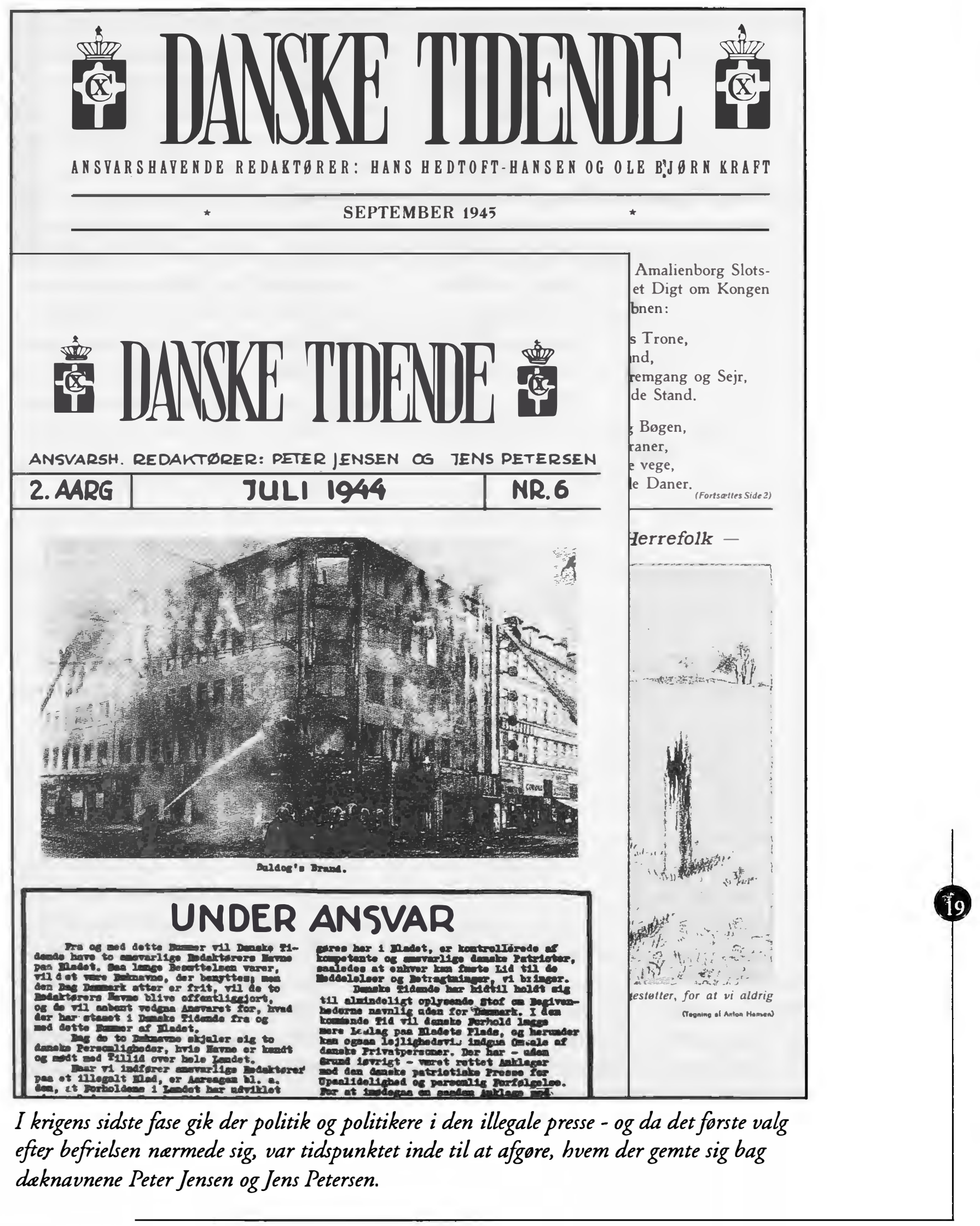


hævede ofte bladarbejdet som en forskoling og en indledning til det egentlige, og det kan heller ikke benægtes, at mange begyndte med bladarbejde for at avancere til mere heltemodige handlinger. Endnu i halvtredsåret for befrielsen kunne en historiker, Henning Poulsen, i en tale om besættelsens eftermæle sige, at den danske modstandsbevægelse var af "næsten rent militær karakter" ${ }^{22}$, skønt der ikke kan være tvivl om, at langt flere mennesker har brugt langt mere tid på at producere den illegale litteratur end på at udøve sabotage.

Bladarbejdet må nødvendigvis have haft en værdi i sig selv. Mens en historiker kan fremture med at overse de illegale blade - der er til dato ikke skrevet et hovedværk om de illegale blade på dansk! - så har det ikke været lige så let for heltene selv. Åge Trommers disputats fra 1971, hvori han fratog jernbanesabotagen dens militære værdi, har haft sin langtidseffekt, selv om den i første omgang blev pure afvist af modstandsfolk. Der er ikke ret mange, heller ikke gamle modstandsfolk, der i dag tør hævde, at sobotagen havde militær værdi. I et foredrag på Frihedsmuseet i København for et års tid siden kunne man høre en af de hårde drenge, Gunnar Dyrberg, konkludere - ikke som man er vant til, at de illegale blade skabte forståelsen for at sabotagen var nødvendig - men tværtimod, at sabotagen var nødvendig for at de illegale blade kunne have en sag at vinde opinionen på. Det er ikke let at blive færdig med den krig, og de illegale blade er vi slet ikke færdige med.

Illegal litteratur fik man overalt i de besatte lande, men ligesom den danske besættelsessituation er noget for sig, er den illegale litteratur i Danmark det også. Fordi vi kom så meget mere lempeligt igennem krigen end så mange andre, kunne man måske have forventet, at vi ikke blot fik en mildere modstandskamp, hvad vi faktisk gjorde, men også en mildere og mindre modstandspresse, hvad vi netop ikke gjorde. Tvætimod. De grumsede danske linier resulterede i en endog meget omfangsrig og frodig illegal litteratur, og den fra begyndelsen uklare situation gjorde i Danmark de fem år til en bevidsthedsproces i endnu højere grad end andre steder. I Danmark blev udviklingen $i$ håb og forventninger, styret som den var af udviklingen på fronterne, skærpet af et skred i holdningen til valget imellem samarbejde og modstand. Den illegale litteratur er både en afspejling af dette skred, propaganda for det og et resultat af det. Og da de 21 millioner eksemplarer af de illegale blade blev til i krigens sidste halvandet år, hvor ingen kunne være i tvivl om, hvordan krigen ville ende, og man heller ikke i udlandet mere kunne være i tvivl om, på hvilken side den danske befolkning befandt sig, kan man måske lidt ondskabsfuldt tilføje, at en del illegale blade også er et resultat af, at en del danskere fik travlt med at placere sig entydigt - ikke i forhold til fronten: for eller imod tyskerne og nazismen, men i forhold til den specielt danske front: for eller imod samarbejde, for eller imod at forsøge at klare sig igennem så let som muligt eller at sætte noget, evt. livet, ind.

Jeg har læst mange illegale blade, og jeg kan have den mistanke, at når besættelsestidshistorikerne har udnyttet 
materialet så lidt, skyldes det også, at det er så omfangsrigt og uoverskueligt. Det er ikke et materiale, som man nemt bringer på formel, når man først har haft øjnene begravet i det i længere tid. Der er f. eks. ikke engang en entydig opbakning bag sabotagen. Der er vidnesbyrd om, at det har været forbundet med både konflikter og diskussioner, om man skulle holde sig til bladarbejdet eller deltage også i aktionsformer, der kunne indebære voldsudøvelse. I en gruppe under De danske Studenter resulterede diskussionerne i sommeren $1943 \mathrm{i}$, at et medlem skrev til Kaj Munk og bad om råd. Kaj Munk svarede kort og godt: "Brænd al den Litteratur - den er saa ligegyldig i Øjeblikket, eller en Klods om Benet - og lær at bruge et Maskingevær. .... Bliv nu et kristent Menneske og lær at slaa ihjel i Jesu Navn .."23 -

Før Kaj Munk fik sit martyrium, var hans eget bidrag til modstandskampen dog ellers netop "litteratur" han kan ikke have haft store tanker om sig selv! - Kaj Munks militante ord overbeviste ikke pigen, der havde skrevet til ham; hun blev ved bladarbejdet, men brød dog ikke kontakten med de kammerater, der gik videre. Også en af heltene, Cato Bakman, som i en kritisk situation satte livet ind og mistede det, havde sat grænsen ved den ikke-voldelige modstandskamp - og altså ikke gjort det for at begrænse sin egen risiko. ${ }^{24}$ Heller ikke i spørgsmålet om stikkerlikvideringer er der enighed, og et nærmere studium af den illegale litteratur og dens baggrund vil utvivlsomt afdække adskillige brudflader og konflikter på trods af, at man plejer at sige, at de illegale blade udgjorde en enig front.

I Norge havde man fra begyndelsen norske tilstande, mens vi i Danmark ikke engang fik det, da vi troede, vi fik det. Samarbejdet forsatte også efter bruddet 29. august, og i krig med tyskerne var det stadig kun modstandsbevægelsen, der var. De rene norske tilstande betød f. eks., at tyskerne inddrog nordmændenes radioapparater, og at den norske illegale presse direkte opstod af et informationsbehov. ${ }^{25}$ Det informationsbehov, der var i Danmark, var derimod kamufleret. Behovet blev dækket legalt med hele og halve sandheder og fortielser, som man først blev sig bevidst, når man vidste bedre. De illegale blades program var også i Danmark at informere og oplyse, men det er påfaldende, at så mange blade $\mathrm{i}$ langt højere grad er debatterende og propaganderende - ikke altid sobert. Den illegale presse var nok fri, men som vi ved også fra vor egen tid, skal der andet end frihed til at skabe en sund presse.

Efterhånden som enden nærmede sig - den blev jo i øvrigt ved med at trække ud, og havde den ikke gjort det, havde den illegale presse været mere overskuelig og danskernes modstandskamp mindre glorværdig - blev efterkrigstiden et vigtigt emne, og der gik både politik og politikere i den illegale presse. Man stillede sig i position til freden. Danske Tidende f.eks. blev nu redigeret af Peter Jensen og Jens Petersen, dæknavne for Ole Bjørn Kraft og Hans Hedtoft, hvilket de afslørede i bladets sidste nummer, der meget passende udkom legalt i september 1945 under valgkampen op til det første valg efter befri- 


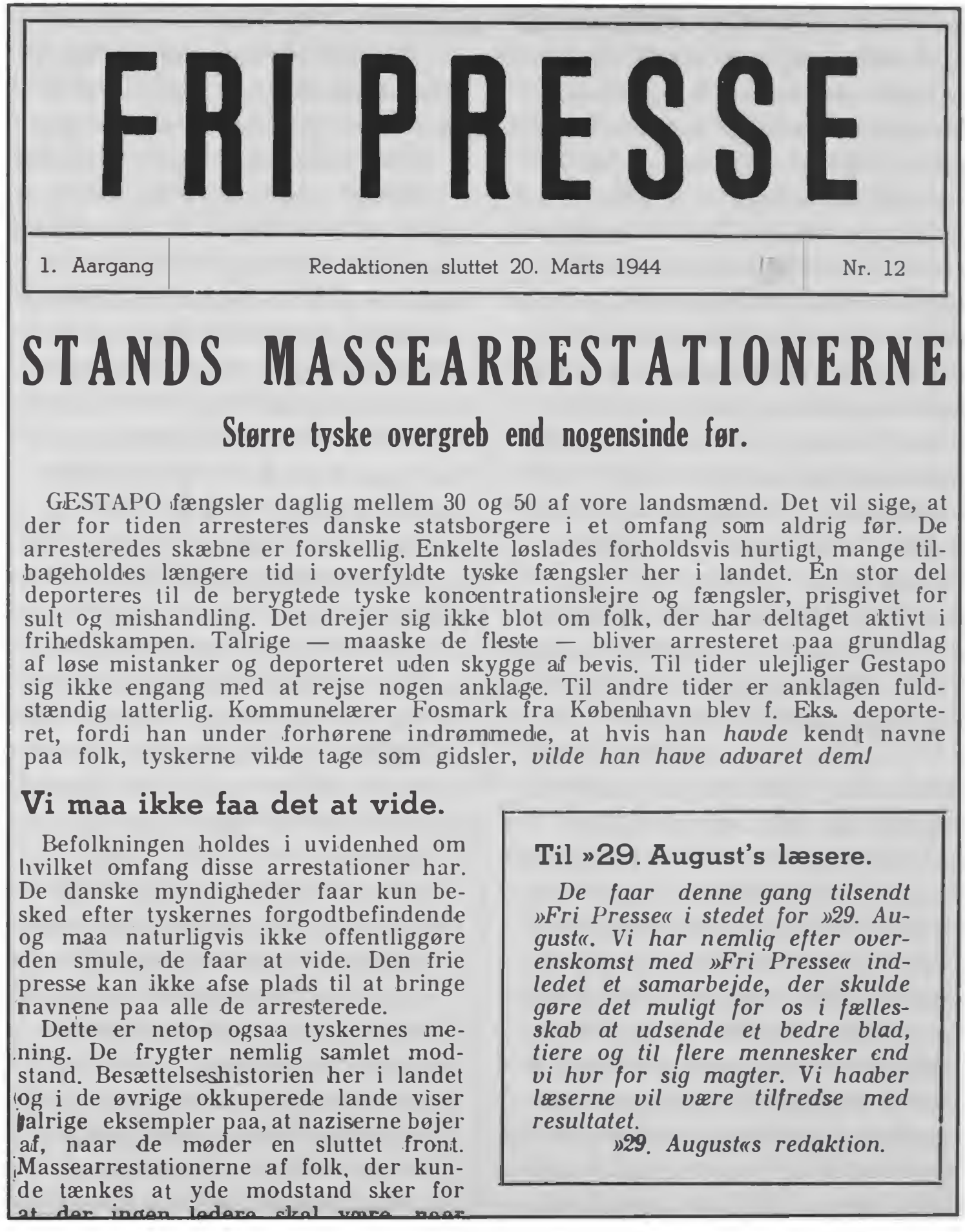

En illegal bladfusion imellem 29. August og Fri Presse, der derefter selv lod sig opkobe af "Ringen" - indtil Fri Presse igen frigjorte sig. 
elsen, hvor danskerne stemte de gamle samarbejdspolitikere ind igen; også de havde jo i virkeligheden været modstandsfolk, og i den sidste ende var det vel også dem, der bedst tegnede befolkningen, både da de samarbejdede med tyskerne, og da de bagefter løb fra det.

I stedet for den gængse forargelse over samarbejdspolitikerne kan vi konstatere, at befolkningen dengang, nøjagtig som i dag, havde de politikere, som den fortjente. Det er forbeholdt andre styreformer end demokratier at kunne lægge ansvaret for udskejelser over på lederne med rette. Politikerleden dengang og i dag lader os blot foregøgle en bekvem enighed, skønt vores, vælgernes, befolkningens, folkets splittede særinteresser er årsagen til miseren. -

Til sidst foregik der i de illegale blade bl. a. en kamp imellem de grupper, der ville bringe erfaringer fra modstandskampen med ind i efterkrigstiden, og som ville opstille et egentligt politisk program, og de grupper, der erklærede sig upolitiske, for hvem kampen havde været et rent nationalt spørgsmål, og som ville opløse sig selv i samme øjeblik tyskerne var ude af landet. De første bestod af de fleste af veteranerne i modstandskampen, og det er karakteristisk, at der tilsyneladende er en bred enighed imellem kommunister, Dansk Samling, Frit Danmark og i hvert fald nogle konservative kredse om at møde freden med ikke blot krav om et retsopgør, men også med krav om sociale forandringer og en udvidelse af demokratiet, herunder et ikke nærmere defineret økonomisk demokrati.

Det var ikke disse samlingsbe- stræbelser, der vandt, men de "upolitiske", hvis politik var at dæmme op for de politiske. Den store modstandsorganisation "Ringen", er et eksempel på denne upolitiske politik. Også denne organisation har sine rødder tilbage omkring årsskiftet 41-42, hvor så meget tog form, men når jeg ikke har næunt den tidligere, er det fordi den som bladorganisation først kom til at spille en rolle i slutningen af krigen, hvor den direkte begyndte at købe andre illegale blade op for at stå stærkere ved befrielsen. Ringens eget blad, Ringen Orientering, udkom første gang 10. marts 1945, men blev da betegnet som 4. årgang nr. 4. Det kunne forsvares med, at bladet havde sin rod helt tilbage i Studieringens første interne skrivelse, nemlig organisationens love fra november 1942, men forklares kan det kun med et ønske om at pynte på fortiden for at kunne tale med større vægt. Det lykkedes i den grad, at historieforfalskningen både for Ringens og mange andre blades vedkommende også blev overtaget af den officielle bibliografi over de illegale tryk, som Det Kongelige Bibliotek udsendte i 1954, og som stadig ikke har fået sin videnskabeligt vederhæftige afløser.

Også den illegale pressetjeneste, som er et af de store vigtige emner, jeg har måttet springe over, spillede sin upolitiske rolle. Efterhånden som censuren blev strammere, gik flere og flere professionelle journalister helt eller delvis over i den illegale presse, og Information blev det store flagskib, som efter den 29. august udviklede sig til et effektivt monopolforetagende, der forsynede både de illegale blade og omverdenen, herun- 
der svensk og engelsk radio, med nyheder fra Danmark. Med kontakter til stort set alle legale og illegale kredse $\mathrm{i}$ Danmark, herunder centraladministrationen og politikerne, som direkte statsfinansierede det illegale foretagende, blev Information, ikke mindst i den sidste fase, efter at Børge Outze var blevet sat ud af spillet ved sin arrestation 14. oktober 1944, til den store pseudonationale manifestation. 2. februar 1945 udsendte Information et såkaldt jubilæumsnummer - "såkaldt", fordi også Informations fødsel fortaber sig i en fiktiv bagudnummerering - heri hed det altomfavnende:

"Medens den legale Presse ydede sin bedste Indsats mod Tyskerne $\mathrm{i}$ Besættelsens første Periode, har den illegale Presse i Besættelsens senere Aar haft en stadig stigende og til sidst helt afgørende Indflydelse paa Skabelsen af den danske Enhedsfront. Den fri Presse har ikke som i Lande, hvor Quislingene blev sat til Styret, været et direkte Modstykke til den legale Presses Billede af Krigens Gang og Løgnagtige Propaganda. Den har først og fremmest været et Korrektiv til den legale Presse. Hvad den legale Presse har maattet fortie, har den oplyst; hvad den legale Presse har skullet lyve om, har den afsløret. Ved dens Esse har den danske Enhedsfront hærdnet sine Vaaben."

\section{Den "enhedsfront", der kom} ud af det, har imidlertid mere med en senere massemedietids nationale sportshysteri at gøre end med den enhedsfront, som de første aktivister drømte om tilbage i 1941 . Hvad udbredelsen og oplaget angår ligger de illegale blades storhedstid imellem valgene i marts
1943 og oktober 1945 , hvor danskerne begge gange gav samarbejdspolitikerne deres fulde tilslutning, og de er altså udtryk for et skred i bevidstheden, som man hurtigt igen distancerede sig fra. Skredet fik til følge, at alle parter i det danske samfund, befolkning, politikere og modstandsbevægelse, kom ud af krigen og befrielsessommeren med et betændt forhold til deres egen fortid. Politikerne og befolkningen løb med i modstandsrusen og glemte, hvad de havde stået for i krigens længste periode. Modstandsbevægelsen endte i opgivende frustration, da Danmark efter valget i efteråret 1945 vendte tilbage til normale tilstande. Den evne til at løbe med og fra standpunkter og gerninger, den opportunisme, som karakteriserer vor tids demokrati og dets demokrater, er også en arv fra besættelsestiden, en arv der har haft mere vind i sejlene end den såkaldte kamp for demokratiet og dets udvidelse.

Det skorter ikke på litteratur om besættelsestiden, men i nyere historieskrivning er der en tendens til at betragte de fem år som en parentes i forhold til den voldsomme samfundsforandring, der allerede var i gang i 30erne, og som især tog fart efter krigen. Men hvis historie er andet end en beskrivelse og registrering af fortiden, hvor man sætter parentes om det, der ikke passer ind $\mathrm{i}$ beskrivelsen af forløbet, hvis historieskrivning f. eks. også er et forsøg på at finde tilbage til energikilder der blev tildækket og afsporet, er besættelsestiden stadig en udfordring. Der går en linie fra den problematiske sejr i 1945 til opløsningen i østeuropa, der i vor tid har fuldbyrdet denne "sejr" og gjort den næ- 
sten total og global, for ikke at sige totalitær, skønt den har bevaret ordet demokrati som sit logo. Sejren er blevet mere fuldkommen, ikke mindre pro-

\section{Noter}

$$
\text { PKIV, s. } 20 .
$$

PKIV, s. 28.

Wilhelm Bergstrøm: Borger $i$ Danmark under Krigen bd. 1- 207, Manuskript, Det Kongelige Bibliotek, Danske afdeling.

$4 \quad$ Citeret efter Nic. Blædel: Forbrydelse og Dumbed, 1946, s. 12.

5 Citeret efter Nic. Blædel: Forbrydelse og Dumbed 1946, s. 13.

6 Det Kongelige Biblioteks illegale samling, Strøsedler og mærkater.

7 Fribedsmuseets samling af illegale skrifter.

* Jørgen Kieler: Arne Sejrs krig, FV-bladet, marts 1996, s. 21.

"Det Kongelige Biblioteks illegale samling, Flyveblad nr. 5 (tysk version)/ Buschardt m.fl: Den illegale presse 1940-45, s. 31 (dansk version).

10 Danske Toner, genudsendt af Midtby DKP, Århus, 1977, med indledning af Børge Houmann.

11 Niels Gyrsting: Om det illegale Land og Folk, Arbejderhistorie, nr. 43, 1994.

12 Det Kongelige Biblioteks illegale samling, Flyveblad nr. 28.

13 Frit Danmarks Hvidbog II, 1946, s. 301. blematisk. I den illegale litteratur ligger der et stort uopdyrket materiale for den, der er interesseret $\mathrm{i}$ at følge begyndelsen til den historie.
14 Jørgen Kieler: Nordens Lenkebunde I, s. 129.

15 Henrik Lundbak: Fra provokation til modstandskamp, Dansk Samling 19411945, 1995, s. 21 og 33.

16 Det Kongelige Biblioteks illegale samling, Flyveblade nr. 46.

17 Hartvig Frisch: Tankt og talt under Krigen, 1945, s. 27.

18 Hans Snitker: Det illegale Frit Danmark bladet og organisationen, 1977, s. 22.

1) Det illegale Frit Danmark 1942-1945, 1946, s. 18.

20 Poul Christensen: Af en illegals erindringer, 1976, s. 64-69.

21 Erik Lund: Fire millioner frie ord, 1970, s. 184.

22 Henning Poulsen: Danmark i krig? Besættelsens eftermæle, Magasin fra Det Kongelige Bibliotek, marts 1997, s. 29.

23 Jørgen Kieler (red.): En modstandsgruppes historie I, 1982, s. 34-34.

24 Jørgen Kieler (red.): En modstandsgruppes historie I, 1982, s. 76

25 Erik Lund: Fire millioner frie ord, 1970, s. 21.

Artiklen bygger på et foredrag, sidst holdt på Lokalhistorisk Arkiv, Fredericia, 16. april 1998. 